\title{
Cost Analysis for Grid-tie PV Electricity Generation System without Battery Backup Considering Panel Aging in Context of Kutubdia Island, Bangladesh
}

\author{
Md. Abubokar Talukdar ${ }^{1}$, Hamidur Rahman ${ }^{2}$, Mohammad Shamsuddoha ${ }^{3}$, Nusrat Nessa ${ }^{4}$ \\ Research Scholar, Department of EEE, Bangladesh University of Engineering and Technology, Dhaka, Bangladesh ${ }^{1}$ \\ Associate Professor, Department of EEE, Bangladesh University of Engineering and Technology, Dhaka, Bangladesh ${ }^{2}$ \\ Electrical Engineer, Bangladesh Power Development Board, Dhaka, Bangladesh ${ }^{3}$ \\ Researcher, Department of EEE, University of Dhaka, Dhaka, Bangladesh ${ }^{4}$
}

\begin{abstract}
Grid-tie PV electricity and cost for per kWh generation are affected by solar irradiances, atmospheric conditions, PV panel and inverter's specifications etc. In this paper, Kutubdia Island, Bangladesh is selected as a site location of PV plant and solar irradiance and atmospheric conditions are considered for this island. Daily total irradiances $\left(\mathrm{kWh} / \mathrm{m}^{2}-\right.$ day) are converted to hourly solar irradiances $\left(\mathrm{W} / \mathrm{m}^{2}\right)$ and these hourly irradiances are used to calculate daily generation of electricity. Specifications of PV panel model no. "Panasonic 325 watt Module 96 Cell HIT - Black Solar Panel" and grid tie inverter model no. "SolarMax 3×330TS-SV Multi MPPT-990kW" are chosen for this research investigation. This battery less PV system exports electricity to the grid during the sun shine hours in the day time only. Energy conversion efficiency reduces significantly due to aging of PV panel over its life time. Linear derated efficiency of PV panel due to aging effect on generation of electricity is considered in this paper. Life time average annual electricity generation is calculated for determination of cost of per kWh electricity.
\end{abstract}

Keywords: Grid-tie system, PV plant, Aging of PV panel, Maximum power point tracker (MPPT), De-rated efficiency.

\begin{tabular}{|c|c|c|c|}
\hline & ENCLATURE & & operating condition \\
\hline$\varnothing$ & Latitude & NOCT & $\begin{array}{l}\text { Nominal operating cell } \\
\text { temperature }\end{array}$ \\
\hline$\lambda$ & Longitude & $\mathrm{T}_{\mathrm{A}}$ & Ambient temperature \\
\hline GMT & Greenwich Mean Time & $\mathrm{T}_{\mathrm{ref}}$ & PV panel reference \\
\hline$\theta$ & $\begin{array}{l}\text { Greenwich Mean } 11 \mathrm{me} \\
\text { Azimuth anole of the sun with }\end{array}$ & & temperature, $25^{\circ} \mathrm{C}$ \\
\hline$\theta_{\text {Azsun }}$ & $\begin{array}{l}\text { Azimuth angle of the sun with } \\
\text { respect to north axis }\end{array}$ & $\mathrm{T}_{\mathrm{C}}(\mathrm{t})$ & Operating PV temperature \\
\hline$\theta_{\mathrm{A}}$ & Altitude angle of the sun & $\mathrm{K}_{\mathrm{V}}$ & $\begin{array}{l}\text { Open circuit voltage co- } \\
\text { efficient }\end{array}$ \\
\hline $\begin{array}{l}\rho \\
\text { GHI }(t)\end{array}$ & $\begin{array}{l}\text { Ground albedo } \\
\text { Global Horizontal Irradiance }\end{array}$ & $\mathrm{K}_{\mathrm{i}}$ & Short circuit current co- \\
\hline $\begin{array}{l}\text { DIF }(t) \\
\text { DHI }(t)\end{array}$ & $\begin{array}{l}\text { Diffuse Horizontal Irradiance } \\
\text { Direct Horizontal Irradiance }\end{array}$ & $\mathrm{E}_{\text {reqday }}$ & $\begin{array}{l}\text { efficient } \\
\text { Daily electricity production }\end{array}$ \\
\hline $\begin{array}{l}\beta_{\text {tilt }} \\
\Theta_{\text {Azpanel }}\end{array}$ & $\begin{array}{l}\text { Solar panel tilt angle } \\
\text { Azimuth angle of PV panel }\end{array}$ & $\mathrm{Mg}$ & $\begin{array}{l}\text { Gradient for the linearly de- } \\
\text { rated efficiency curve }\end{array}$ \\
\hline $\mathrm{G}(\mathrm{t})$ & $\begin{array}{l}\text { with respect to south axis. } \\
\text { Solar irradiance on tilted } \\
\text { surface }\end{array}$ & $\begin{array}{l}\eta_{\text {inv }} \\
\eta_{\text {trans }}\end{array}$ & $\begin{array}{l}\text { Efficiency of inverter } \\
\text { Efficiency of transformer }\end{array}$ \\
\hline $\mathrm{V}_{\text {OCSTC }}$ & $\begin{array}{l}\text { Open circuit voltage under } \\
\text { standard test condition }\end{array}$ & $\begin{array}{l}\mathrm{FF} \\
\mathrm{f}_{\text {exploit }}\end{array}$ & $\begin{array}{l}\text { Fill factor } \\
\text { Area exploitation factor }\end{array}$ \\
\hline $\mathrm{V}_{\mathrm{OC}}(\mathrm{t})$ & $\begin{array}{l}\text { Open circuit voltage under } \\
\text { operating condition }\end{array}$ & $\begin{array}{l}\text { Area }_{\text {grid }} \\
\mathrm{N}_{\text {lifepv }}\end{array}$ & $\begin{array}{l}\text { Grid substation area } \\
\text { Life time of PV panel }\end{array}$ \\
\hline $\mathrm{I}_{\mathrm{SCSTC}}$ & $\begin{array}{l}\text { Short circuit current under } \\
\text { standard test condition }\end{array}$ & $\begin{array}{l}\mathrm{N}_{\text {lifeinv }} \\
\mathrm{N}_{\text {lifesupport }}\end{array}$ & $\begin{array}{l}\text { Life time of PV inverter } \\
\text { Life time of PV panel supports }\end{array}$ \\
\hline $\mathrm{I}_{\mathrm{SC}}(\mathrm{t})$ & Short circuit current under & $\mathrm{N}_{\text {lifesubstation }}$ & Life time of grid substation \\
\hline
\end{tabular}




\section{International Journal of Innovative Research in Electrical, Electronics, Instrumentation and Control Engineering}

\section{ISO 3297:2007 Certified}

Vol. 5, Issue 3, March 2017

\begin{tabular}{|c|c|}
\hline $\mathrm{N}_{\text {lifeland }}$ & Life time of land \\
\hline $\mathrm{N}_{\text {lifeproject }}$ & Life time of project \\
\hline Price $_{\text {purpv }}$ & $\begin{array}{l}\text { Purchasing price of PV panels } \\
\text { per watt }\end{array}$ \\
\hline Price $_{\text {purinv }}$ & $\begin{array}{l}\text { Purchasing price of PV inverter } \\
\text { per watt }\end{array}$ \\
\hline Price $_{\text {supportpv }}$ & $\begin{array}{l}\text { Price for support of PV panels } \\
\text { per } m^{2}\end{array}$ \\
\hline Price $_{\text {substation }}$ & $\begin{array}{l}\text { Construction price of grid } \\
\text { substation per volt-ampere }\end{array}$ \\
\hline Price $_{\text {purland }}$ & $\begin{array}{l}\text { Purchasing price of land per } \\
\text { acres }\end{array}$ \\
\hline Price $_{\text {landdev }}$ & $\begin{array}{l}\text { Cost of land development per } \\
\text { acres }\end{array}$ \\
\hline$\%$ Salvage $e_{p v}$ & $\begin{array}{l}\text { Percentage of salvage value of } \\
\text { PV panels, of its initial } \\
\text { investment }\end{array}$ \\
\hline$\%$ Salvage inverter & $\begin{array}{l}\text { Percentage of salvage value of } \\
\text { PV inverter, of its initial } \\
\text { investment }\end{array}$ \\
\hline$\%$ Salvage support & $\begin{array}{l}\text { Percentage of salvage value of } \\
\text { PV panel supports, of its initial } \\
\text { investment }\end{array}$ \\
\hline$\%$ Salvage substation & $\begin{array}{l}\text { Percentage of salvage value of } \\
\text { grid substation, of its initial } \\
\text { investment }\end{array}$ \\
\hline$\%$ Salvage $e_{\text {land }}$ & $\begin{array}{l}\text { Percentage of salvage value of } \\
\text { land, of its initial investment }\end{array}$ \\
\hline$\beta$ & Inflation rate \\
\hline$\gamma$ & Interest rate \\
\hline$\Psi$ & Escalation rate \\
\hline$N_{\text {techstaff }}$ & $\begin{array}{l}\text { No. of technical staffs per } \\
M W_{p}\end{array}$ \\
\hline$N_{\text {secustaff }}$ & No. of security staffs per $M W_{p}$ \\
\hline Salary $_{\text {techstaff }}$ & Salary of each technical staff \\
\hline Salary $_{\text {secustaff }}$ & Salary of each security guard \\
\hline Price $_{\text {ompv }}$ & $\begin{array}{l}\text { Yearly maintenance cost of PV } \\
\text { panel per watt }\end{array}$ \\
\hline Price $_{\text {omsupport }}$ & $\begin{array}{l}\text { Yearly maintenance cost of PV } \\
\text { panel support per } m^{2}\end{array}$ \\
\hline Price $_{\text {ominv }}$ & $\begin{array}{l}\text { Yearly maintenance cost of PV } \\
\text { inverter per watt }\end{array}$ \\
\hline Price $_{\text {omsubstation }}$ & $\begin{array}{l}\text { Yearly maintenance cost of grid } \\
\text { substation per watt. }\end{array}$ \\
\hline Price $_{\text {omland }}$ & $\begin{array}{l}\text { Yearly maintenance cost of } \\
\text { land per acre. }\end{array}$ \\
\hline
\end{tabular}

\section{INTRODUCTION}

A grid tie PV system omitting the energy storage device like large capacity battery bank not only reduces the internal losses for charging and discharging of battery bank but also cost of the system. Maximum generation of PV power can be evacuated to grid instantly. For grid tie system, voltage wave shape of inverter's output must be identical to the grid voltage. Since voltage wave shape of grid is sinusoidal, so inverter should be sinusoidal wave inverter. Although sinusoidal wave inverter is little more expensive in comparison with other voltage wave inverters, but omission of large battery bank may offer more reduction of cost. Kutubdia Island has sufficient solar insolation $\left(3.5-5.5 \mathrm{kWh} / \mathrm{m}^{2}-\right.$ day) [1] and huge barren land. Kutubdia has not yet been connected with grid electricity, but Bangladesh Power Development Board (BPDB) has already launched a project to connect this island with grid electricity. In this research Kutubdia Island is selected as a site location for a large size PV plant (several $M W_{p}$ ).

\section{GRID-TIE PV SYSTEM WITHOUT BATTERY BACKUP}

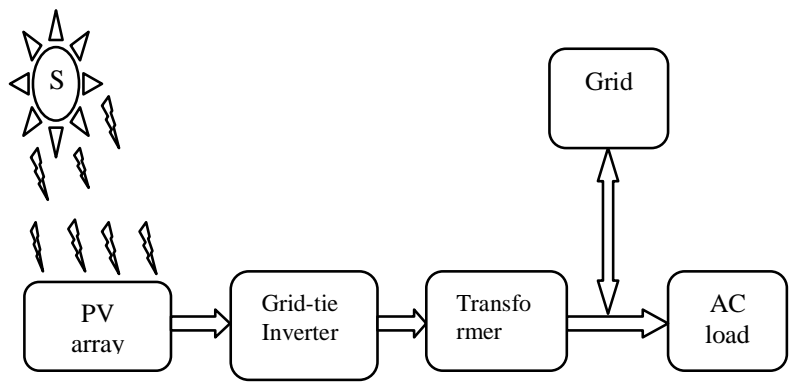

Fig.1: Block diagram for Grid-tie PV System without Battery Backup

Wattpeak $\left(W_{p}\right)$ rating of PV panel is the maximum amount of power converted by PV panel under standard test conditions (STC). Under standard test condition, solar irradiance level is $1000 \mathrm{~W} / \mathrm{m}^{2}$, panel temperature is $25^{\circ} \mathrm{C}$ and air mass (AM) is 1.5 [2]. Power conversion from panel varies for different times of a day as solar irradiance changes. Even in solar day peak time power produced from the panel is less than $W_{p}$ as solar irradiance level is less than $1000 \mathrm{~W} / \mathrm{m}^{2}$ for the location of Kutubdia. Gridtie inverter is a maximum power point tracker (MPPT) embedded sinusoidal wave inverter. The embedded MPPT extracts maximum power output of the PV panels and inverter converts DC voltage to sinusoidal wave AC voltage. Output voltage of inverter is stepped up using suitable turns ratio of transformer to adjust with grid voltage. Power ratings of both inverter and transformer depend on total wattpeak $\left(W_{p}\right)$ rating of PV plant.

\section{III.CONVERSION OF DAILY TOTAL IRRADIANCE TO HOURLY IRRADIANCES}

Solar declination angle in degree, $\delta$, is as [3].

$$
\delta=23.45 \times \operatorname{Sin}\left(\frac{360(N+284)}{365}\right)
$$

Where, $\mathrm{N}=\mathrm{N}$ th day of a year.

The values of the equation of time (ET) in minute as a function of the day of the year $(\mathrm{N})$ can be obtained approximately from the following equation [3], [4]. 
$E T=229.18(0.0000075+0.001868 \cos (\mathrm{d})-0.032077$

$\sin (d)-0.014615 \cos (2 d)-0.040849 \sin (2 d)) \ldots .2$

Where, Factor $\mathrm{d}=\frac{2 \pi(N-1)}{365}$

Relationship between local standard time (LST) and solar apparent time (AST) is given by the following equation.

$$
\mathrm{AST}=\mathrm{LST}+\frac{E T+4 \times\left(\lambda_{s t}-\lambda\right)}{60} \quad \ldots .3
$$

Where, $\lambda_{s t}=$ Local standard longitude and $\lambda=$ Local longitude.

Expression for solar hour angle $(\omega)$ and sun set hour angle $\left(\omega_{S S}\right)$ in degree as specified in [3], [4].

$$
\begin{gathered}
\omega=15 \times(A S T-12) \ldots \ldots 4 \\
\omega_{s S}=\operatorname{Cos}^{-1}(-\tan \varnothing \tan \delta) \ldots \ldots
\end{gathered}
$$

Relation between hourly irradiance $G_{h}(\mathrm{t})$ and daily total irradiance $G_{d a y}$ can be expressed according to Liu-Jordan correlation [5].

$$
G_{h}(t)=\left\{\frac{\frac{\pi}{24}\left(\operatorname{Cos} \omega(t)-\operatorname{Cos} \omega_{s s}\right.}{\operatorname{Sin} \omega_{s s}-\frac{2 \pi \omega_{s S}}{360} \operatorname{Cos} \omega_{s s}}\right\} \times G_{\text {day }} ; \quad \ldots 6
$$

$0 \leq \mathrm{t} \leq 24$ and $\mathrm{t}$ is LST in hour.

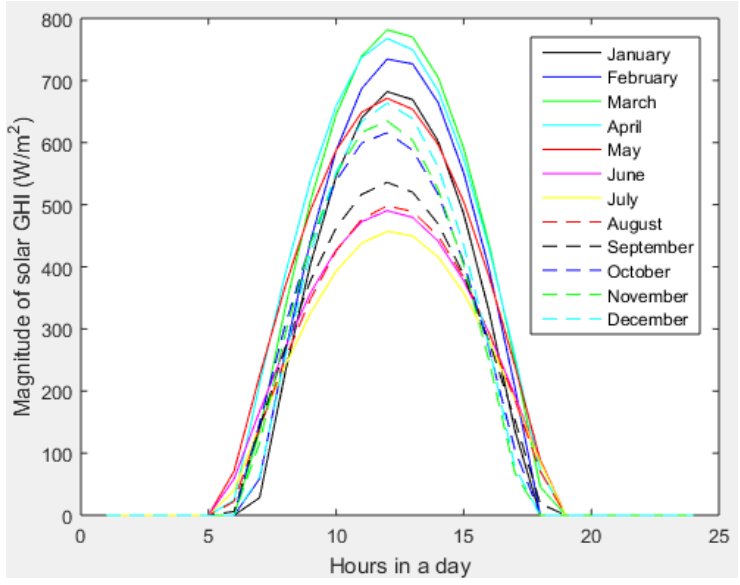

Fig. 2 Diurnal variation of GHI for January to December at location of Kutubdia Island, Bangladesh.

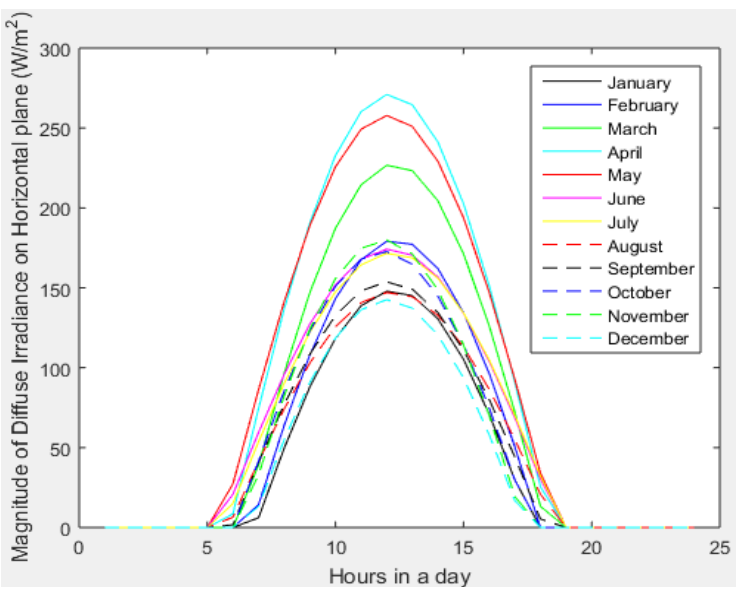

Fig. 3 Diurnal variation of DIF for January to December at location of Kutubdia Island, Bangladesh.

\section{IV.DETERMINATION OF SOLAR IRRADIANCE ON TILTED PV PANEL}

PV panels are yearly fixed to a certain tilt angle and azimuth orientation so that yearly total solar irradiances incident on PV panel surface is maximum. For Bangladesh yearly fixed tilt and azimuth angles are $21.8^{\circ}$ (equal to latitude) and $0^{\circ}[14]$ respectively. Solar irradiance on tilted PV panel for different hours (i.e., $0 \leq \mathrm{t} \leq 24$ ) is calculated using equations as follows.

Direct Beam on Tilted Surface [6]-[7],

$$
\begin{gathered}
\operatorname{DIRT}_{\text {tilt }}(t)= \\
\max \left\{0, \frac{\operatorname{Sin} \theta_{A} \operatorname{Cos} \beta+\operatorname{Cos} \theta_{A} \operatorname{Sin} \beta \operatorname{Cos}\left(\theta_{\text {Azsun }}-\theta_{\text {Azpvn }}\right)}{\operatorname{Sin} \theta_{A}}\right\} \times \\
\{G H I(t)-\operatorname{DIF}(t)\} \\
\ldots .7
\end{gathered}
$$

Where, $\Theta_{\text {Azpvn }}$ is the azimuth angle of PV panel with respect to north axis and so $\Theta_{\text {Azpvn }}=180^{\circ}+\Theta_{\text {Azpanel }}$.

Diffuse beam on tilted surface is calculated by Pseudoisotropic model proposed by authors in [8].

$$
D I F_{\text {tilt }}(t)=\left(\frac{3+\operatorname{Cos}\left(2 \beta_{\text {tilt }}\right)}{4}\right) \times D I F(t) \quad \ldots .8
$$

Using equation as in [9] ground reflected beam on tilted surface,

$$
R E F_{\text {tilt }}(t)=\rho\left(\frac{1-\operatorname{Cos} \beta_{\text {tilt }}}{2}\right) \times G H I(t) \ldots \ldots .9
$$

Solar irradiance on tilted surface,

$$
G(t)=D I R T_{\text {tilt }}(t)+D I F_{\text {tilt }}(t)+R E F_{\text {tilt }}(t) \quad \ldots \ldots .10
$$

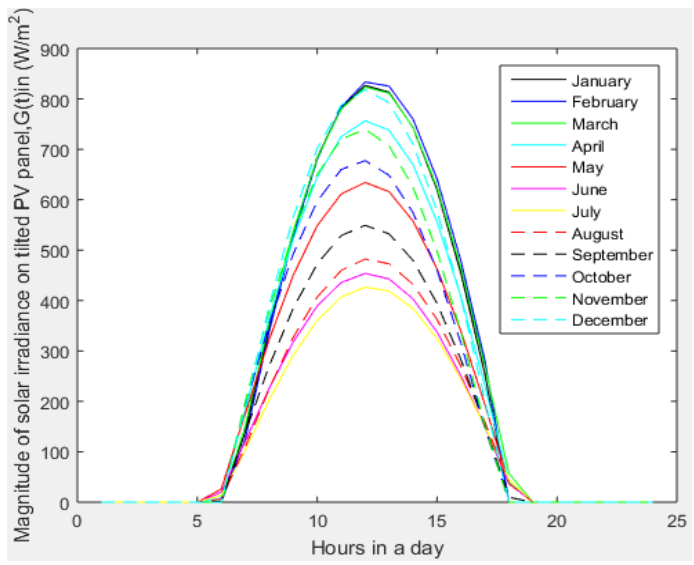

Fig. 4 Diurnal variation of $G(t)$ for January to December at location of Kutubdia Island, Bangladesh.

\section{A PV SYSTEM MODEL AND CALCULATION OF PV PLANT AREA}

Power produced by the PV panel can be calculated using following equations [10].

Open circuit voltage:

$$
\mathrm{V}_{\mathrm{OC}}(\mathrm{t})=\mathrm{V}_{\text {OCSTC }}+\mathrm{K}_{\mathrm{v}}\left(\mathrm{T}_{\mathrm{C}}(\mathrm{t})-\mathrm{T}_{\text {ref }}\right) \quad \ldots . .11
$$


Vol. 5, Issue 3, March 2017

Short circuit current:

$$
I_{S C}(t)=\left[I_{S C S T C}+K_{i}\left(T_{C}(t)-T_{\text {ref }}\right)\right] \times \frac{G(t)}{1000} \ldots 12
$$

Where

$$
\mathrm{T}_{\mathrm{C}}(\mathrm{t})=\mathrm{T}_{\mathrm{A}}+\frac{\text { NOCT }-20}{800} \times \mathrm{G}(\mathrm{t}) \ldots 13
$$

Instantaneous power produced from a panel,

$$
\mathrm{P}_{\text {Panelnew }}(\mathrm{t})=\eta_{\text {inv }} \times \eta_{\text {trans }} \times \mathrm{FF} \times \mathrm{V}_{\mathrm{OC}}(\mathrm{t}) \times \mathrm{I}_{\mathrm{SC}}(\mathrm{t}) \quad \ldots 14
$$

\section{A. Annual average electricity production by a new PV} panel

Annual average electricity production by a PV panel can be calculated using following relationships.

Daily electricity production by a new panel,

$$
\begin{gathered}
\mathrm{E}_{\text {Pdnew }}=\sum_{\mathrm{t}=1}^{24} \mathrm{P}_{\text {Panelnew }}(\mathrm{t}) \\
=\eta_{\text {inv }} \times \eta_{\text {trans }} \times \mathrm{FF} \times \sum_{\mathrm{t}=1}^{24} \mathrm{~V}_{\mathrm{OC}}(\mathrm{t}) \times \mathrm{I}_{\mathrm{SC}}(\mathrm{t}) \ldots .15
\end{gathered}
$$

Annual electricity production by a new panel,

$$
\mathrm{E}_{\text {Pynew }}=\sum_{\mathrm{d}=1}^{365} \mathrm{E}_{\text {Pdnew }}(\mathrm{d})
$$

Where, $\mathrm{d}=$ day

B. Consideration of aging of PV panel and life time average annual electricity production by a PV panel Due to aging of PV panel, energy conversion efficiency reduces. Curve for de-rating of PV panel efficiency is collected from manufacturer's data sheet of PV panel. Linear de-rating of efficiency of PV panel as shown in figure below is obtained from technical specification of panel data and de-rated efficiency is represented in equation 17.

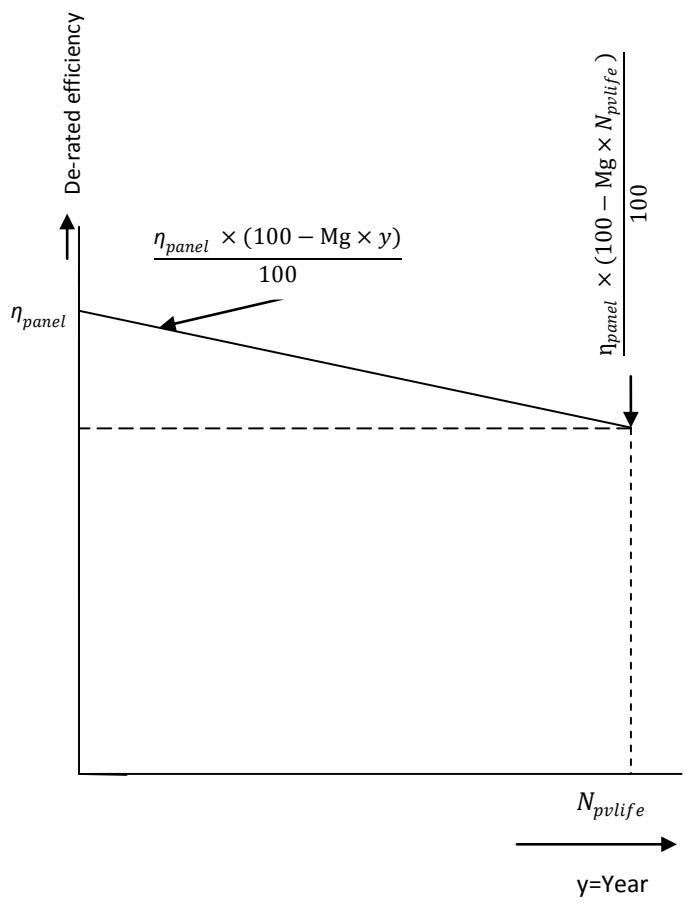

Fig. 5 Curve for de-rating of efficiency due to aging of PV panel.

$$
\text { De-rated efficiency }=\frac{\eta_{\text {panel }} \times(100-\mathrm{Mg} \times y)}{100}
$$

Where, $\eta_{\text {panel }}$ is the efficiency of a PV panel at new condition. PV panel life time average of annual electricity production by a panel,

$$
\mathrm{E}_{\text {Pyavg }}=\frac{\mathrm{E}_{\text {Pynew }} \quad \sum_{\mathrm{y}=0}^{\mathrm{N}_{\text {lifepv }}-1} \frac{(100-\mathrm{Mg} \times \mathrm{y})}{100}}{\mathrm{~N}_{\text {lifepv }}} \ldots .18
$$

\section{Area for PV plant}

Annual target of electricity,

$$
\mathrm{E}_{\text {reqyear }}=365 \times \mathrm{E}_{\text {reqday }} \quad \ldots . .19
$$

Number of panels required

$$
\mathrm{N}_{\mathrm{pv}}=\text { Ceiling }\left(\frac{\mathrm{E}_{\text {reqyear }}}{E_{\text {Pyavg }}}\right) \quad \ldots .20
$$

Watt-peak rating of PV plant,

$$
\text { Wpeak }_{\mathrm{PV}}=\text { Wattpeak }_{\text {Panel }} \times \mathrm{N}_{\mathrm{PV}} \quad \ldots .21
$$

Solar radiation sensitive panel area,

$$
\text { Area }_{\text {Panel }}=\text { Length }_{\text {Panel }} \times \text { Width }_{\text {Panel }} \ldots .22
$$

PV panel installation area in acre,

$$
\text { Area }_{\mathrm{PV}}=\frac{\mathrm{N}_{\mathrm{PV}} \times \text { Area }_{\text {Panel }}}{\mathrm{f}_{\text {exploit }}} \times \frac{1}{4046.8} \ldots .23
$$

Total PV plant area,

$$
\text { Area }_{\text {Plant }}=\text { Area }_{\mathrm{PV}}+\text { Area }_{\text {grid }} \quad \ldots 24
$$

\section{COST ESTIMATION FOR GRID TIE PV PLANT}

\section{A. Initial investment}

Initial investment for purchasing PV panels,

$$
\text { Invest }_{\text {purpv }}=\text { Price }_{\text {purpv }} \times \text { Wattpeak }_{\mathrm{PV}} \ldots .25
$$

Considering record high irradiance $\left(\mathrm{G}=880 \mathrm{~W} / \mathrm{m}^{2}\right)$ on $\mathrm{PV}$ panel and record low temperature $\left(\mathrm{T}_{\mathrm{A}}=5^{\circ} \mathrm{C}\right)$, for Kutubdia Island, record maximum power of PV plant, $\mathrm{P}_{\mathrm{PVmax}}$ is calculated as below.

$$
\mathrm{P}_{\mathrm{PVmax}}=\mathrm{N}_{\mathrm{pv}} \times \mathrm{FF} \times \mathrm{V}_{\mathrm{OC}}(\mathrm{t}) \times \mathrm{I}_{\mathrm{SC}}(\mathrm{t}) \quad \ldots .26
$$

Power rating of inverter,

$$
\text { Watt }_{\text {inv }}=\mathrm{P}_{\mathrm{PVmax}} \ldots .27
$$

Apparent power rating of transformer,

$$
\text { Watt }_{\text {substation }}=\eta_{\text {inv }} \times \text { Watt }_{\text {inv }} \times \frac{1}{\text { Powerfactor }} \ldots 28
$$

Initial investment for purchasing PV inverter,

$$
\text { Invest }_{\text {inverter }}=\text { Price }_{\text {purinv }} \times \mathrm{Watt}_{\text {inv }}
$$

Initial investment for construction of panel supports,

$$
\text { Invest }_{\text {support }}=\text { Price }_{\text {supportpv }} \times \text { Area }_{\text {pv }} \ldots . .30
$$

Initial investment for grid substation,

$$
\text { Invest }_{\text {substation }}=\text { Price }_{\text {substation }} \times \text { Watt }_{\text {substation }} \ldots . .31
$$


Initial investment for purchasing land,

$$
\text { Invest }_{\text {land }}=\text { Price }_{\text {purland }} \times \text { Area }_{\text {plant }} \ldots . .32
$$

Initial investment for land development,

$$
\text { Invest }_{\text {landdev }}=\text { Price }_{\text {landdev }} \times \text { Area }_{\text {plant }} \ldots . .33
$$

\section{B. Present worth of salvage value}

Present worth of salvage value is calculated as in [11] using following equations.

Present worth of salvage value of PV panels,

$$
\mathrm{PSV}_{\text {panel }}=\% \text { Salvage }_{\mathrm{pv}} \times \text { Invest }_{\text {purpv }} \times\left(\frac{1+\beta}{1+\gamma}\right)^{\mathrm{N}_{\text {lifepv }}} \ldots .34
$$

Present worth of salvage value of PV inverter,

PSV $_{\text {inverter }}=\%$ Salvage $_{\text {inv }} \times$ Invest $_{\text {purinv }} \times\left(\frac{1+\beta}{1+\gamma}\right)^{\mathrm{N}_{\text {lifeinv }}} . .35$

Present worth of salvage value of panel supports,

$$
\begin{aligned}
\text { PSV }_{\text {support }} & =\% \text { Salvage } \\
& \times\left(\frac{1+\beta}{1+\gamma}\right)^{N_{\text {lifesupport }}} \ldots . .36
\end{aligned}
$$

Present worth of salvage value of grid substation,

$$
\begin{gathered}
\text { PSV }_{\text {substation }}=\% \text { Salvage }_{\text {substation }} \\
\text { Invest }_{\text {substation }} \times\left(\frac{1+\beta}{1+\gamma}\right)^{\mathrm{N}_{\text {lifesubstation }}} \ldots
\end{gathered}
$$

Present worth of salvage value of land,

$\mathrm{PSV}_{\text {land }}=\%$ Salvage land $\times$ Invest $_{\text {land }} \times\left(\frac{1+\beta}{1+\gamma}\right)^{\mathrm{N}_{\text {lifeland }}} \ldots 38$

\section{Present worth of maintenance cost}

Present worth of maintenance cost is calculated as in [11] using following equations.

Present worth of maintenance cost of PV panels,

$$
\mathrm{OM}_{\mathrm{pv}}=\text { Price }_{\mathrm{ompv}} \times \text { Wattpeak }_{\mathrm{pv}} \sum_{\mathrm{i}=1}^{\mathrm{N}_{\text {lifepv }}}\left(\frac{1+\psi}{1+\gamma}\right)^{\mathrm{i}} \ldots 39
$$

Present worth of maintenance cost of PV inverter,

$$
\mathrm{OM}_{\text {inverter }}=\text { Price }_{\text {ominv }} \times \text { Watt }_{\text {inv }} \sum_{\mathrm{i}=1}^{\mathrm{N}_{\text {lifeinv }}}\left(\frac{1+\psi}{1+\gamma}\right)^{\mathrm{i}} \ldots 40
$$

Present worth of maintenance cost of PV panels supports,

$$
\begin{gathered}
\text { OM }_{\text {support }}= \\
\text { Price }_{\text {omsupport } \times \text { Area }_{\text {pv }} \sum_{\mathrm{i}=1}^{\mathrm{N}_{\text {lifesupport }}}}\left(\frac{1+\psi}{1+\gamma}\right)^{\mathrm{i}} \ldots 41
\end{gathered}
$$

Present worth of maintenance cost of grid substation,

$$
\begin{gathered}
\mathrm{OM}_{\text {substation }}= \\
\text { Price }_{\text {omsubstation }} \times \mathrm{Watt}_{\text {substation }} \sum_{\mathrm{i}=1}^{\mathrm{N}_{\text {lifesubstation }}} \\
\left(\frac{1+\psi}{1+\gamma}\right)^{\mathrm{i}} \ldots 42
\end{gathered}
$$

Present worth of maintenance cost of land development,

$$
\mathrm{OM}_{\text {landdev }}=\text { Price }_{\text {omland }} \times \text { Area }_{\text {plant }} \cdot \sum_{\mathrm{i}=1}^{\mathrm{N}_{\text {lifeland }}}\left(\frac{1+\psi}{1+\gamma}\right)^{\mathrm{i}} \ldots 43
$$

Present worth of operating cost (Salary of staffs),

$$
\begin{aligned}
& \mathrm{OM}_{\text {salary }}=\left(\text { Salary }_{\text {techstaff }} \times \mathrm{N}_{\text {techstaff }} \times \frac{\text { Wpeak }_{\mathrm{PV}}}{10^{6}}+\right. \\
& \text { Salary } \left._{\text {secustaff }} \times \mathrm{N}_{\text {secustaff }} \times \frac{\text { Wpeak pv }_{\text {pv }}}{10^{6}}\right) \times 14.2 \times \\
& \sum_{\mathrm{i}=1}^{\mathrm{N}_{\text {lifeproject }}}\left(\frac{1+\psi}{1+\gamma}\right)^{\mathrm{i}} \ldots 44
\end{aligned}
$$

\section{Total annual cost}

Annual cost of PV plant is calculated using following equations [5].

Annual cost for solar panels,

$$
\text { Cost }_{\text {panels }}=\frac{\text { Invest }_{\text {purpv }}-\mathrm{PSV}_{\text {panel }}+\mathrm{OM}_{\mathrm{pv}}}{\mathrm{N}_{\text {lifepv }}} \ldots .45
$$

Annual cost for panel supports,

$$
\text { Cost }_{\text {support }}=\frac{\text { Invest support }-\mathrm{PSV}_{\text {support }}+\mathrm{OM}_{\text {support }}}{\mathrm{N}_{\text {lifesupport }}} \ldots 46
$$

Annual cost for PV inverter,

$$
\text { Cost }_{\text {inverter }}=\frac{\text { Invest }_{\text {inverter }}-\mathrm{PSV}_{\text {inverter }}+\mathrm{OM}_{\text {inverter }}}{\mathrm{N}_{\text {lifeinverter }}} \ldots 47
$$

Annual cost for grid substation,

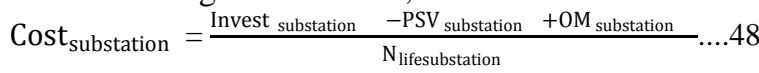

Annual cost for land,

$$
\text { Cost }_{\text {land }}=\frac{\text { Invest }_{\text {land }}+\text { Invest }_{\text {landdev }}-\mathrm{PSV}_{\text {land }}+\mathrm{OM}_{\text {land }}}{\mathrm{N}_{\text {lifeland }}} \ldots 49
$$

Annual cost for salary of staff,

$$
\text { Cost }_{\text {salary }}=\frac{\mathrm{OM}_{\text {salary }}}{\mathrm{N}_{\text {lifeproject }}} \ldots .50
$$

Total Annual cost,

$$
\begin{gathered}
\text { Cost }_{\text {year }}=\text { Cost }_{\text {panels }}+\text { Cost }_{\text {support }}+\text { Cost }_{\text {inverter }}+ \\
\text { Cost }_{\text {substation }}+\text { Cost }_{\text {land }}+\text { Cost }_{\text {salary }}
\end{gathered}
$$

E. Per unit electricity $(\mathrm{kWh})$ generation cost

Per unit electricity $(\mathrm{kWh})$ generation cost in BDT,

$$
\mathrm{kWh}_{\text {cost }}=\frac{\text { Cost }_{\text {year }}}{E_{\text {Pyavg }} / 1000} \ldots .52
$$

\section{INPUT DATA}

Direct beam incident on tilted PV panel is calculated using equation 7. Altitude angle of the sun $\left(\Theta_{A}\right)$ and azimuth angle of sun with respect to north axis $\left(\Theta_{\text {Azsun }}\right)$ for middle days of every months of a year is listed in table "TABLE I: Altitude and Azimuth angle of the sun for Kutubdia Island" in appendix. These angles are collected from online software tool (sunearthtool) [12].

Input solar data are hourly solar irradiances on titled PV panels as shown in fig.4. Prices for PV panels, inverter and transformer are collected from [13].

TABLE -1 LOCATION DATA

\begin{tabular}{|l|l|}
\hline Latitude, $\varnothing$ & $21.8^{\circ}$ \\
\hline Longitude of Kutubdia Island, $\lambda$ & $91.85^{\circ}$ \\
\hline Local standard longitude of Bangladesh, $\lambda_{s t}$ & $90^{\circ}$ \\
\hline
\end{tabular}


International Journal of Innovative Research in Electrical, Electronics, Instrumentation and Control Engineering

\section{ISO 3297:2007 Certified}

Vol. 5, Issue 3, March 2017

Average ambient temperature of Kutubdia $30^{\circ} \mathrm{C}$ Island, $T_{A}$

\section{TABLE -2 DESIGN SPECIFIED DATA}

\begin{tabular}{|l|l|}
\hline $\begin{array}{l}\text { Daily electricity production } \\
\text { target, } E_{\text {reqday }}\end{array}$ & $24 \times 10^{6} \mathrm{Wh}$ \\
\hline Grid substation area, Area $a_{\text {grid }}$ & 1 acre \\
\hline Area exploitation factor, $f_{\text {exploit }}$ & 0.6 \\
\hline Solar panel tilt angle, $\beta_{\text {tilt }}$ & $\begin{array}{l}21.8^{\circ} \text { (equal to } \\
\text { latitude) [14]. }\end{array}$ \\
\hline Solar panel azimuth angle, $A_{\text {zpanel }}$ & $0^{\circ}$ \\
\hline
\end{tabular}

\section{TABLE -3DEVICE SPECIFICATION DATA}

\begin{tabular}{|c|c|}
\hline $\begin{array}{l}\text { Watt-peak rating of each panel, Wp } \\
(\text { in W) }\end{array}$ & 325 \\
\hline $\begin{array}{l}\text { Efficiency of panel at new condition, } \\
\eta_{\text {Panel }} \text { (in \%) }\end{array}$ & 19.4 \\
\hline $\begin{array}{l}\text { Gradient of the linearly de-rated panel } \\
\text { efficiency, } M_{g}\left(\text { in } y e a r^{-1}\right)\end{array}$ & -1 \\
\hline $\begin{array}{l}\text { Dimension of each PV panel (Length } \\
\times \text { Width) } \\
\left(\text { in } m^{2}\right)\end{array}$ & $\begin{array}{l}1.590 \times 1 \\
053\end{array}$ \\
\hline $\begin{array}{l}\text { Open circuit voltage of each panel under } \\
\text { STC, Voc.stc (in V) }\end{array}$ & 69.6 \\
\hline $\begin{array}{l}\text { Short circuit current of each panel under } \\
\text { STC, Isc.stc (in A) }\end{array}$ & 6.03 \\
\hline $\begin{array}{l}\text { Temperature coefficient of open circuit } \\
\text { voltage of PV panel, } K_{v}\left(\text { in } \mathrm{V} /{ }^{\circ} \mathrm{C}\right)\end{array}$ & -0.174 \\
\hline $\begin{array}{l}\text { Temperature Coefficient of short circuit } \\
\text { current of PV panel, } K_{i}\left(\text { in } \mathrm{A} /{ }^{\circ} \mathrm{C}\right)\end{array}$ & +0.00182 \\
\hline Fill Factor, FF & 0.774 \\
\hline $\begin{array}{l}\text { Nominal Operating Cell Temperature of } \\
\text { PV panel , NOCT (in }{ }^{\circ} \mathrm{C} \text { ) }\end{array}$ & 49.2 \\
\hline $\begin{array}{l}\text { Efficiency of grid tie PV inverter, } \eta_{\text {inv }} \\
\text { (in\%) }\end{array}$ & 95 \\
\hline Efficiency of transformer, $\eta_{\text {trans }}$ (in\%) & 97 \\
\hline
\end{tabular}

TABLE -4 COST ESTIMATION DATA

\begin{tabular}{|c|l|}
\hline$N_{\text {lifepv }}$ & 25 years \\
\hline$N_{\text {lifeinv }}$ & 5 years \\
\hline$N_{\text {lifesupport }}$ & 25 years \\
\hline$N_{\text {lifesubstation }}$ & 25 years \\
\hline$N_{\text {lifeland }}$ & 25 years \\
\hline$N_{\text {lifeproject }}$ & 25 years \\
\hline Price $_{\text {purpv }}$ & BDT $110 / \mathrm{Watt}$ \\
\hline Price $_{\text {purinv }}$ & BDT $15 / \mathrm{Watt}$ \\
\hline Price $_{\text {supportpv }}$ & BDT 5000/m \\
\hline Price $_{\text {substation }}$ & BDT $10 / \mathrm{VA}$ \\
\hline Price $_{\text {purland }}$ & BDT 500 lac/acre \\
\hline Price $_{\text {landdev }}$ & BDT: 5 lac/acre \\
\hline
\end{tabular}

\begin{tabular}{|c|c|}
\hline$\%$ Salvage & $20 \%$ \\
\hline$\%$ Salvage $_{\text {inverter }}$ & $20 \%$ \\
\hline$\%$ Salvage $e_{\text {support }}$ & $20 \%$ \\
\hline$\%$ Salvage substation & $20 \%$ \\
\hline$\%$ Salvage land $_{\text {la }}$ & $100 \%$ \\
\hline$\beta$ & 0.08 \\
\hline$\gamma$ & 0.12 \\
\hline$\Psi$ & 0.10 \\
\hline$N_{\text {techstaff }}$ & $3 \mathrm{men} / M W_{p}$ \\
\hline$N_{\text {secustaff }}$ & $3 \mathrm{men} / M W_{p}$ \\
\hline Salary $_{\text {techstaff }}$ & BDT 30000/man \\
\hline Salary secustaff $_{\text {st }}$ & BDT $20000 /$ man \\
\hline Price $_{\text {ompv }}$ & BDT 5/ Watt \\
\hline Price $_{\text {omsupport }}$ & BDT $200 / m^{2}$ \\
\hline Price $_{\text {ominv }}$ & BDT 1/Watt \\
\hline Price $_{\text {omsubstation }}$ & BDT 1/VA \\
\hline Price $_{\text {omland }}$ & BDT 0.5lac /acre \\
\hline
\end{tabular}

\section{VI.RESULT}

Total watt peak rating of PV plant, total area of the plant and cost for per $\mathrm{kWh}$ PV electricity generation are calculated using equations 21,24 and 52 respectively. Matlab software version "MATLAB R2015a" is used for these calculations. Hourly solar irradiance for a particular hour is assumed as a constant for the particular duration of an hour. For example solar irradiance at 11:30am is assumed to be same for 11:00am to $12: 00 \mathrm{pm}$ for a particular day. Diurnal solar irradiances are determined for middle days of every months of a year and it is assumed that diurnal solar irradiance for middle of a month is identical for remaining days of that month.

TABLE -5 RESULT

\begin{tabular}{|l|l|}
\hline Total watt peak rating of PV plant & $6.53 M W_{p}$ \\
\hline Total area of the plant & 14.85 acres \\
\hline Cost for per kWh PV electricity & BDT 14.87 \\
\hline
\end{tabular}

\section{CONCLUSION}

Cost for per $\mathrm{kWh}$ electricity generation is very important for planning a new power plant. Due to aging of power plant generation of electricity reduces. Reduction of generation must be taken into account to enhance the accuracy of the calculations. Battery less grid tie PV system mainly consists of PV panels, grid tie inverter and transformer. As price of inverter and transformer is significantly less than the price of PV panels, cost of PV electricity significantly depends on prices and solar performances of PV panels. Moreover de-rating of efficiencies over the lifetime of inverter and transformer is very less than that of PV panels. Consideration of derating of efficiency of PV panels can give significantly accurate result for calculation of cost and amount of electricity from a battery less grid tie system. 


\section{International Journal of Innovative Research in Electrical, Electronics, Instrumentation and Control Engineering}

\section{ISO 3297:2007 Certified}

Vol. 5, Issue 3, March 2017

\section{REFERENCES}

[1] Sanjoy Kumar Nandi, Himangshu Ranjan Ghosh,“Technoeconomical analysis of off-grid hybrid systems at Kutubdia Island, Bangladesh", Energy Policy, Volume 38, Issue 2, February 2010, Pages 976-980.

[2] Wohlgemuth,John H., "Standards for PV Modules and Components - Recent Developments and Challenges," 27th European Photovoltaic Solar Energy Conference and Exhibition, Frankfurt, Germany, September 24-28, 2012

[3] Daryl R. Myers, "Solar Time and Solar Position," Solar Radiation Practical Modeling for Renewable Energy Applications, 1st ed. New York, CRC Press, 2013, ch.1, sec.1.31, pp.3-4.

[4] Soteris A. Kalogirou. (2014). Basic Solar Geometry [Online]. Available URL: http://web.cut.ac.cy/wpcontent/uploads/sites/13/2014/08/1-1-b-Basic-Solar-Geometry.pdf, accessed on date $29^{\text {th }}$ Jan 2017.

[5] Garg, H.P and Garg.,S.N, “ Improved correlation of daily and hourly diffuse radiation with global radiation for Indian stations." Solar and Wind Technology,1999, Vol. 4, no. 2, pp. 113-126.

6] M. Gulin, M. Va`sak, and N. Peri'c, "Dynamical optimal positioning of a photovoltaic panel in all weather conditions," Applied Energy, vol. 108, pp. 429-438, August 2013.

[7] Gulin, Marko, Mario Vašak, and Mato Baotic. "Estimation of the global solar irradiance on tilted surfaces." 17th International Conference on Electrical Drives and Power Electronics (EDPE 2013). 2013.

[8] V. Badescu, "3D isotropic approximation for solar diffuse irradiance on tilted surfaces," Renewable Energy, vol. 26, no. 2, pp. 221-233, June 2002.

9] H.R. Ghosh, N.C. Bhowmik and M. Hussain, "Determining seasonal optimum tilt angles, solar radiations on variously oriented, single and double axis tracking surfaces at Dhaka, Renewable Energy, Volume 35, Issue 6, June 2010, Pages 1292-1297

[10] Alsayed, M., Cacciato, M., Scarcella, G. and Scelba, G., "Multicriteria Optimal Sizing of Photovoltaic-Wind Turbine Grid Connected Systems ,' IEEE Transactions on Energy Conversion ,Vol.28, Issue. 2 , pp. 370-379,2013.

[11] Wang, Lingfeng and Singh, Chanan, "Multicriteria Design of Hybrid Power Generation Systems Based on a Modified Particle Swarm Optimization Algorithm,' 'IEEE Transactions on Energy Conversion, Vol.24, Issue 1, pp. 163 - 172, 2009.

[12] http://www.sunearthtools.com/dp/tools/pos_sun.php?lang=en,acces sed on $25^{\text {th }}$ Feb 2017

[13] http://www.wholesalesolar.com/, accessed on $25^{\text {th }}$ Feb 2017.

[14] Md. Saifur Rahman et al., "Solar Energy and Solar Electricity," Solar Home System, first edition, Dhaka, Bangladesh: Department of Electrical and Electronic Engineering, BUET, 2013, ch. 1, sec. 1.14 , pp. $45-46$

\section{BIOGRAPHIES}

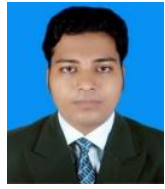

Md. Abubokar Talukdar received the B.Sc in Electrical and Electronic Engineering and M.S in Nuclear
Engineering from "Chittagong University of Engineering and Technology" and "University of Dhaka" respectively. $\mathrm{He}$ is pursuing the M.Sc in Electrical and Electronic Engineering from "Bangladesh University of Engineering and Technology". He worked as a lecturer in Electrical, Electronics and Telecommunication Engineering at Dhaka International University, Bangladesh from 2011 to 2013. $\mathrm{He}$ is currently working as an electrical engineer in Bangladesh Power Development Board, Dhaka. He also works as a co-supervisor of several undergraduate and post graduate researches on electrical power system and renewable energy at University of Dhaka.

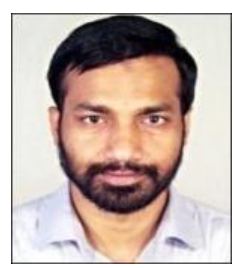

Hamidur Rahman is currently working as an associate professor in Electrical and Electronic Engineering in Bangladesh University of Engineering and Technology. His research interests are renewable energy, power system, and control system engineering. He is currently supervising several post graduate researches on renewable energy.

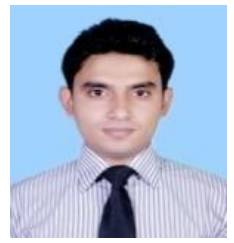

Mohammad Shamsuddoha received the B.Sc in Electrical and Electronic Engineering and M.S in Nuclear Engineering from "Chittagong University of Engineering and Technology" and "University of Dhaka" respectively. He is currently working as an electrical engineer in Bangladesh Power Development Board, Dhaka. He also works as a researcher of University of Dhaka. He is currently researching on diversification of fuel sources to generate grid electricity in Bangladesh.

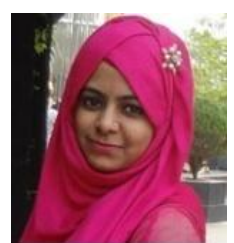

Nusrat Nessa received the B.Sc in Electrical and Electronic Engineering from University of Dhaka. She is pursuing the M.Sc in Electrical and Electronic Engineering from the same university. She is now working as a post graduate researcher of EEE in University of Dhaka.

\section{APPENDIX}

TABLE- I ALTITUDE AND AZIMUTH ANGLE OF THE SUN FOR KUTUBDIA ISLAND

\begin{tabular}{|c|c|c|c|c|c|c|c|c|c|c|c|c|}
\hline \multicolumn{13}{|c|}{$\begin{array}{l}\text { Name of location: Kutubdia Island, Bangladesh; Latitude, } \varnothing=21.82^{\circ} \mathrm{N} \text {, } \\
\text { Longitude, long }=91.85^{\circ} \mathrm{E}, \mathrm{GMT}=+6 \text {, Ground albedo, } \rho=0.2\end{array}$} \\
\hline \multirow{2}{*}{$\begin{array}{l}\text { Hours } \\
\text { in a } \\
\text { day }\end{array}$} & \multicolumn{12}{|c|}{ Azimuth angle of the sun, $\Theta_{\text {Azsun }}$ / Altitude angle of the sun, $\theta_{A}$ in degree for middle days of different months in a year } \\
\hline & $15^{\text {th }}$ Jan & $\begin{array}{l}14^{\text {th }} \\
\text { Feb }\end{array}$ & $\begin{array}{l}15^{\text {th }} \\
\text { Mar }\end{array}$ & $\begin{array}{l}15^{\text {th }} \\
\text { Apr }\end{array}$ & $\begin{array}{l}15^{\text {th }} \\
\text { May }\end{array}$ & $\begin{array}{l}15^{\text {th }} \\
\text { Jun }\end{array}$ & $15^{\text {th }} \mathrm{Jul}$ & $\begin{array}{l}15^{\text {th }} \\
\text { Aug }\end{array}$ & $\begin{array}{l}15^{\text {th }} \\
\text { Sep }\end{array}$ & $\begin{array}{l}15^{\text {th }} \\
\text { Oct }\end{array}$ & $\begin{array}{l}15^{\text {th }} \\
\text { Nov }\end{array}$ & $\begin{array}{l}15^{\text {th }} \\
\text { Dec }\end{array}$ \\
\hline 1:00 & $88.93 /$ & $48.48 /$ & $29.77 /$ & $23.65 /$ & $19.90 /$ & $16.62 /$ & $15.48 /$ & $19.01 /$ & $30.84 /$ & $55.09 /$ & $80.58 /$ & $98.76 /$ \\
\hline
\end{tabular}


International Journal of Innovative Research in Electrical, Electronics, Instrumentation and Control Engineering

ISO 3297:2007 Certified

Vol. 5, Issue 3, March 2017

\begin{tabular}{|c|c|c|c|c|c|c|c|c|c|c|c|c|}
\hline & -79.77 & -77.49 & -67.97 & -56.15 & -47.20 & -43.11 & -45.05 & -52.04 & -61.22 & -69.52 & -73.72 & -76.65 \\
\hline 2:00 & $\begin{array}{l}93.53 / \\
-65.85 \\
\end{array}$ & $\begin{array}{l}74.02 / \\
-65.09 \\
\end{array}$ & $\begin{array}{l}55.75 / \\
-58.33 \\
\end{array}$ & $\begin{array}{l}44.25 / \\
-48.27 \\
\end{array}$ & $\begin{array}{l}37.31 / \\
-40.47 \\
\end{array}$ & $\begin{array}{l}32.96 / \\
-37.23 \\
\end{array}$ & $\begin{array}{l}32.68 / \\
-39.32 \\
\end{array}$ & $\begin{array}{l}38.59 / \\
-45.27 \\
\end{array}$ & $\begin{array}{l}52.35 / \\
-51.87 \\
\end{array}$ & $\begin{array}{l}72.90 / \\
-56.93 \\
\end{array}$ & $\begin{array}{l}89.14 / \\
-59.86 \\
\end{array}$ & $\begin{array}{l}98.63 / \\
-62.88 \\
\end{array}$ \\
\hline 3:00 & $\begin{array}{l}96.99 / \\
-51.99\end{array}$ & $\begin{array}{r}83.92 / \\
-51.41 \\
\end{array}$ & $\begin{array}{l}69.59 / \\
-45.90 \\
\end{array}$ & $\begin{array}{l}57.99 / \\
-37.37 \\
\end{array}$ & $\begin{array}{l}50.15 / \\
-30.79 \\
\end{array}$ & $\begin{array}{l}45.54 / \\
-28.38 \\
\end{array}$ & $\begin{array}{l}45.84 / \\
-30.48 \\
\end{array}$ & $\begin{array}{l}52.52 / \\
-35.29\end{array}$ & $\begin{array}{r}65.44 / \\
-39.92\end{array}$ & $\begin{array}{l}82.15 / \\
-43.34\end{array}$ & $\begin{array}{l}94.21 / \\
-45.95 \\
\end{array}$ & $\begin{array}{l}100.74 / \\
-49.15\end{array}$ \\
\hline 4:00 & $\begin{array}{l}100.48 / \\
-38.23 \\
\end{array}$ & $\begin{array}{l}90.21 / \\
-37.51 \\
\end{array}$ & $\begin{array}{l}78.33 / \\
-32.51 \\
\end{array}$ & $\begin{array}{l}67.45 / \\
-24.97 \\
\end{array}$ & $\begin{array}{l}59.52 / \\
-19.38 \\
\end{array}$ & $\begin{array}{l}54.94 / \\
-17.65 \\
\end{array}$ & $\begin{array}{l}55.60 / \\
-19.68 \\
\end{array}$ & $\begin{array}{l}62.38 / \\
-23.54 \\
\end{array}$ & $\begin{array}{l}74.24 / \\
-26.84 \\
\end{array}$ & $\begin{array}{l}88.60 / \\
-29.47 \\
\end{array}$ & $\begin{array}{l}98.57 / \\
-32.12 \\
\end{array}$ & $\begin{array}{l}103.66 / \\
-54.54\end{array}$ \\
\hline 5:00 & $\begin{array}{l}104.2 / \\
-24.63\end{array}$ & $\begin{array}{l}95.39 / \\
-23.59\end{array}$ & $\begin{array}{l}84.90 / \\
-18.72 \\
\end{array}$ & $\begin{array}{l}74.56 / \\
-11.79 \\
\end{array}$ & $\begin{array}{l}66.60 / \\
-6.96\end{array}$ & $\begin{array}{l}62.06 / \\
-5.76 \\
\end{array}$ & $\begin{array}{l}62.95 / \\
-7.70\end{array}$ & $\begin{array}{l}69.75 / \\
-10.81\end{array}$ & $\begin{array}{l}80.95 / \\
-13.25\end{array}$ & $\begin{array}{l}94.09 / \\
-15.55 \\
\end{array}$ & $\begin{array}{r}102.9 / \\
-18.44\end{array}$ & $\begin{array}{l}107.2 / \\
-22.12\end{array}$ \\
\hline 6:00 & $\begin{array}{l}108.5 / \\
-11.27 \\
\end{array}$ & $\begin{array}{l}100.4 / \\
-9.80 \\
\end{array}$ & $\begin{array}{l}90.60 / \\
-4.81 \\
\end{array}$ & $\begin{array}{l}80.41 / \\
1.81 \\
\end{array}$ & $\begin{array}{l}72.23 / \\
6.09 \\
\end{array}$ & $\begin{array}{l}67.60 / \\
6.85 \\
\end{array}$ & $\begin{array}{l}68.69 / 5 \\
.01\end{array}$ & $\begin{array}{l}75.67 / \\
2.45 \\
\end{array}$ & $\begin{array}{l}86.74 / \\
0.59 \\
\end{array}$ & $\begin{array}{l}99.45 / \\
-1.73 \\
\end{array}$ & $\begin{array}{l}107.79 / \\
-5.02\end{array}$ & $\begin{array}{l}111.52 / \\
-8.99 \\
\end{array}$ \\
\hline 7:00 & $\begin{array}{l}113.71 / \\
1.725\end{array}$ & $\begin{array}{l}105.83 / \\
3.766\end{array}$ & $\begin{array}{l}96.22 / 9 \\
10\end{array}$ & $\begin{array}{l}85.74 / 1 \\
5.635\end{array}$ & $\begin{array}{l}76.98 / 1 \\
9.516\end{array}$ & $\begin{array}{l}72.06 / 1 \\
9.918\end{array}$ & $\begin{array}{l}73.37 \\
/ 18.71\end{array}$ & $\begin{array}{l}80.82 / 1 \\
6.112\end{array}$ & $\begin{array}{l}92.34 / 1 \\
4.51\end{array}$ & $\begin{array}{l}105.34 / \\
11.86\end{array}$ & $\begin{array}{l}113.53 / \\
8.00\end{array}$ & $\begin{array}{l}116.86 / \\
3.714\end{array}$ \\
\hline 8:00 & $\begin{array}{l}120.19 / \\
14.15 \\
\end{array}$ & $\begin{array}{l}112.25 / \\
16.94 \\
\end{array}$ & $\begin{array}{l}102.46 / \\
22.85 \\
\end{array}$ & $\begin{array}{l}91.18 / 2 \\
9.56\end{array}$ & $\begin{array}{l}81.26 / 3 \\
3.19 \\
\end{array}$ & $\begin{array}{l}75.71 / 3 \\
3.30 \\
\end{array}$ & $\begin{array}{l}77.33 / 3 \\
1.65 \\
\end{array}$ & $\begin{array}{l}85.74 / 2 \\
9.94\end{array}$ & $\begin{array}{l}98.48 / 2 \\
8.36 \\
\end{array}$ & $\begin{array}{l}112.47 / \\
25.03 \\
\end{array}$ & $\begin{array}{l}120.76 / \\
20.40\end{array}$ & $\begin{array}{l}123.67 / \\
15.75 \\
\end{array}$ \\
\hline 9:00 & $\begin{array}{l}128.65 / \\
25.65\end{array}$ & $\begin{array}{l}120.50 / \\
29.43\end{array}$ & $\begin{array}{l}110.28 / \\
36.22\end{array}$ & $\begin{array}{l}97.55 / 4 \\
3.45\end{array}$ & $\begin{array}{l}85.49 / 4 \\
7.02\end{array}$ & $\begin{array}{l}78.70 / 4 \\
6.88\end{array}$ & $\begin{array}{l}80.84 / 4 \\
5.31\end{array}$ & $\begin{array}{l}91.07 / 4 \\
3.85\end{array}$ & $\begin{array}{l}106.21 / \\
41.96\end{array}$ & $\begin{array}{l}121.97 / \\
37.43\end{array}$ & $\begin{array}{l}130.35 / \\
31.74\end{array}$ & $\begin{array}{l}132.63 / \\
26.71\end{array}$ \\
\hline $10: 00$ & $\begin{array}{l}140.04 / \\
35.65\end{array}$ & $\begin{array}{l}131.89 / \\
40.71\end{array}$ & $\begin{array}{l}121.46 / \\
48.78\end{array}$ & $\begin{array}{l}106.66 / \\
57.07\end{array}$ & $\begin{array}{l}90.39 / 6 \\
0.94\end{array}$ & $\begin{array}{l}80.93 / 6 \\
0.58\end{array}$ & $\begin{array}{l}84.08 / 5 \\
9.12\end{array}$ & $\begin{array}{l}98.05 / 5 \\
7.72\end{array}$ & $\begin{array}{l}117.74 / \\
54.89\end{array}$ & $\begin{array}{l}135.74 / \\
48.31\end{array}$ & $\begin{array}{l}143.53 / \\
41.28\end{array}$ & $\begin{array}{l}144.63 / \\
35.95\end{array}$ \\
\hline 11:00 & $\begin{array}{l}155.35 / \\
43.14\end{array}$ & $\begin{array}{l}148.31 / \\
49.71\end{array}$ & $\begin{array}{l}139.64 / \\
59.50\end{array}$ & $\begin{array}{l}124.28 / \\
69.73\end{array}$ & $\begin{array}{l}98.69 / 7 \\
4.82\end{array}$ & $\begin{array}{l}81.33 / 7 \\
4.35\end{array}$ & $\begin{array}{l}87.35 / 7 \\
2.99\end{array}$ & $\begin{array}{l}111.05 / \\
71.23\end{array}$ & $\begin{array}{l}138.66 / \\
65.94\end{array}$ & $\begin{array}{l}156.38 / \\
56.16\end{array}$ & $\begin{array}{l}161.36 / \\
47.77\end{array}$ & $\begin{array}{l}160.35 / \\
42.42\end{array}$ \\
\hline $12: 00$ & $\begin{array}{l}174.48 / \\
46.82 \\
\end{array}$ & $\begin{array}{l}170.86 / \\
54.66\end{array}$ & $\begin{array}{l}169.74 / \\
65.59 \\
\end{array}$ & $\begin{array}{l}171.28 / \\
77.71 \\
\end{array}$ & $\begin{array}{l}164.78 / \\
86.87\end{array}$ & $\begin{array}{l}49.07 / 8 \\
7.71 \\
\end{array}$ & $\begin{array}{l}93.73 / 8 \\
6.92 \\
\end{array}$ & $\begin{array}{l}158.84 / \\
81.80\end{array}$ & $\begin{array}{l}178.00 / \\
71.32 \\
\end{array}$ & $\begin{array}{l}183.65 / \\
58.61\end{array}$ & $\begin{array}{l}182.81 / \\
49.70\end{array}$ & $\begin{array}{l}179.12 / \\
44.93\end{array}$ \\
\hline 13:00 & $\begin{array}{l}194.68 / \\
45.70\end{array}$ & $\begin{array}{l}195.95 / \\
53.83\end{array}$ & $\begin{array}{l}205.00 / \\
63.75\end{array}$ & $\begin{array}{l}228.10 / \\
72.50\end{array}$ & $\begin{array}{l}259.70 / \\
76.42\end{array}$ & $\begin{array}{l}279.51 / \\
77.80\end{array}$ & $\begin{array}{l}270.91 / \\
79.14\end{array}$ & $\begin{array}{l}237.92 / \\
76.28\end{array}$ & $\begin{array}{l}218.74 / \\
66.68\end{array}$ & $\begin{array}{l}209.66 / \\
54.53\end{array}$ & $\begin{array}{l}203.62 / \\
46.47\end{array}$ & $\begin{array}{l}198.05 / \\
42.82\end{array}$ \\
\hline $14: 00$ & $\begin{array}{l}212.23 / \\
40.11\end{array}$ & $\begin{array}{l}216.91 / \\
47.56\end{array}$ & $\begin{array}{l}229.58 / \\
55.19\end{array}$ & $\begin{array}{l}250.25 / \\
60.14\end{array}$ & $\begin{array}{l}269.01 / \\
62.56\end{array}$ & $\begin{array}{l}278.71 / \\
64.04\end{array}$ & $\begin{array}{l}274.45 / \\
65.23\end{array}$ & $\begin{array}{l}257.83 / \\
63.27\end{array}$ & $\begin{array}{l}240.87 / \\
55.90\end{array}$ & $\begin{array}{l}228.28 / \\
45.68\end{array}$ & $\begin{array}{l}220.21 / \\
39.04\end{array}$ & $\begin{array}{l}214.11 / \\
36.66\end{array}$ \\
\hline $15: 00$ & $\begin{array}{l}225.67 / \\
31.32 \\
\end{array}$ & $\begin{array}{l}231.76 / \\
37.79 \\
\end{array}$ & $\begin{array}{l}244.12 / \\
43.49 \\
\end{array}$ & $\begin{array}{l}260.66 / \\
46.93 \\
\end{array}$ & $\begin{array}{l}274.08 / \\
48.64 \\
\end{array}$ & $\begin{array}{l}280.67 / \\
50.31 \\
\end{array}$ & $\begin{array}{l}277.65 / \\
51.39 \\
\end{array}$ & $\begin{array}{l}266.31 / \\
49.47 \\
\end{array}$ & $\begin{array}{l}252.88 / \\
43.06 \\
\end{array}$ & $\begin{array}{l}240.69 / \\
34.30 \\
\end{array}$ & $\begin{array}{l}232.32 / \\
28.94 \\
\end{array}$ & $\begin{array}{l}226.41 / \\
27.62 \\
\end{array}$ \\
\hline $16: 00$ & $\begin{array}{l}235.59 / \\
20.54\end{array}$ & $\begin{array}{l}242.14 / \\
26.10\end{array}$ & $\begin{array}{l}253.55 / \\
30.50\end{array}$ & $\begin{array}{l}267.49 / \\
33.08\end{array}$ & $\begin{array}{l}278.35 / \\
34.81\end{array}$ & $\begin{array}{l}283.50 / \\
36.69\end{array}$ & $\begin{array}{l}281.02 / \\
37.65 \\
\end{array}$ & $\begin{array}{l}272.08 / \\
35.55\end{array}$ & $\begin{array}{l}260.81 / \\
29.49\end{array}$ & $\begin{array}{l}249.41 / \\
21.65\end{array}$ & $\begin{array}{l}241.19 / \\
17.27 \\
\end{array}$ & $\begin{array}{l}235.60 / \\
16.78 \\
\end{array}$ \\
\hline $17: 00$ & $\begin{array}{l}243.05 / \\
8.56\end{array}$ & $\begin{array}{l}249.80 / \\
13.39\end{array}$ & $\begin{array}{l}260.55 / \\
16.93\end{array}$ & $\begin{array}{l}273.08 / \\
19.17\end{array}$ & $\begin{array}{l}282.61 / \\
21.12\end{array}$ & $\begin{array}{l}286.98 / \\
23.26\end{array}$ & $\begin{array}{l}284.75 / \\
24.07\end{array}$ & $\begin{array}{l}277.06 / \\
21.67\end{array}$ & $\begin{array}{l}267.01 / \\
15.34\end{array}$ & $\begin{array}{l}256.11 / \\
8.34\end{array}$ & $\begin{array}{l}247.95 / \\
4.68\end{array}$ & $\begin{array}{l}242.57 / \\
4.82\end{array}$ \\
\hline $18: 00$ & $\begin{array}{l}248.88 /- \\
4.16\end{array}$ & $\begin{array}{l}255.90 / \\
0.084\end{array}$ & $\begin{array}{l}266.44 / \\
3.104\end{array}$ & $\begin{array}{l}278.39 / \\
5.32\end{array}$ & $\begin{array}{l}287.30 / \\
7.67\end{array}$ & $\begin{array}{l}291.21 / \\
10.10\end{array}$ & $\begin{array}{l}289.07 / \\
10.75\end{array}$ & $\begin{array}{l}282.04 / \\
7.93\end{array}$ & $\begin{array}{l}272.611 \\
.71\end{array}$ & $\begin{array}{l}261.77 / \\
-5.33\end{array}$ & $\begin{array}{l}253.39 / \\
-8.46\end{array}$ & $\begin{array}{l}248.02 / \\
-7.84\end{array}$ \\
\hline 19:00 & $\begin{array}{l}253.63 /- \\
17.34 \\
\end{array}$ & $\begin{array}{l}261.19 / \\
-13.56 \\
\end{array}$ & $\begin{array}{l}272.05 / \\
-10.81 \\
\end{array}$ & $\begin{array}{l}284.08 / \\
-8.34 \\
\end{array}$ & $\begin{array}{l}292.81 / \\
-5.41 \\
\end{array}$ & $\begin{array}{l}296.45 / \\
-2.64 \\
\end{array}$ & $\begin{array}{l}294.28 / \\
-2.20 \\
\end{array}$ & $\begin{array}{l}287.56 / \\
-5.54 \\
\end{array}$ & $\begin{array}{l}278.32 / \\
-12.16 \\
\end{array}$ & $\begin{array}{l}267.07 / \\
-19.19 \\
\end{array}$ & $\begin{array}{l}258.04 / \\
-21.96 \\
\end{array}$ & $\begin{array}{l}252.40 / \\
-20.94 \\
\end{array}$ \\
\hline 20:00 & $\begin{array}{l}257.70 /- \\
30.83\end{array}$ & $\begin{array}{l}266.24 / \\
-27.39 \\
\end{array}$ & $\begin{array}{l}278.07 / \\
-24.67\end{array}$ & $\begin{array}{l}290.82 / \\
-21.62 \\
\end{array}$ & $\begin{array}{l}299.70 / \\
-17.90\end{array}$ & $\begin{array}{l}303.11 / \\
-14.74\end{array}$ & $\begin{array}{l}300.83 / \\
-14.56 \\
\end{array}$ & $\begin{array}{l}294.21 / \\
-18.56\end{array}$ & $\begin{array}{l}284.88 / \\
-25.81 \\
\end{array}$ & $\begin{array}{l}272.64 / \\
-33.12 \\
\end{array}$ & $\begin{array}{l}262.32 / \\
-35.68\end{array}$ & $\begin{array}{l}256.01 / \\
-34.34\end{array}$ \\
\hline 21:00 & $\begin{array}{l}261.34 /- \\
44.52 \\
\end{array}$ & $\begin{array}{l}271.68 / \\
-41.30 \\
\end{array}$ & $\begin{array}{l}285.43 / \\
-38.30 \\
\end{array}$ & $\begin{array}{l}299.60 / \\
-34.22 \\
\end{array}$ & $\begin{array}{l}308.76 / \\
-29.43 \\
\end{array}$ & $\begin{array}{l}311.86 / \\
-25.80 \\
\end{array}$ & $\begin{array}{l}309.39 / \\
-25.97 \\
\end{array}$ & $\begin{array}{l}302.88 / \\
-30.82 \\
\end{array}$ & $\begin{array}{l}293.37 / \\
-38.98 \\
\end{array}$ & $\begin{array}{l}279.46 / \\
-46.97 \\
\end{array}$ & $\begin{array}{l}266.67 / \\
-49.53 \\
\end{array}$ & $\begin{array}{l}258.96 / \\
-47.93 \\
\end{array}$ \\
\hline 22:00 & $\begin{array}{l}264.85 /- \\
58.33\end{array}$ & $\begin{array}{l}278.72 / \\
-55.16\end{array}$ & $\begin{array}{l}295.98 / \\
-51.34\end{array}$ & $\begin{array}{l}312.06 / \\
-45.54\end{array}$ & $\begin{array}{l}321.14 / \\
-39.31\end{array}$ & $\begin{array}{l}323.56 / \\
-35.20\end{array}$ & $\begin{array}{l}320.93 / \\
-35.82\end{array}$ & $\begin{array}{l}314.91 / \\
-41.70\end{array}$ & $\begin{array}{l}305.89 / \\
-51.13\end{array}$ & $\begin{array}{l}289.87 / \\
-60.46\end{array}$ & $\begin{array}{l}272.01 / \\
-63.45\end{array}$ & $\begin{array}{l}261.14 / \\
-61.64\end{array}$ \\
\hline 23:00 & $\begin{array}{l}268.78 /- \\
72.23\end{array}$ & $\begin{array}{l}291.10 / \\
-68.63\end{array}$ & $\begin{array}{l}314.02 / \\
-62.82\end{array}$ & $\begin{array}{l}330.70 / \\
-54.30\end{array}$ & $\begin{array}{l}337.96 / \\
-46.42\end{array}$ & $\begin{array}{l}338.96 / \\
41.95\end{array}$ & $\begin{array}{l}336.38 / \\
-43.12\end{array}$ & $\begin{array}{l}332.13 / \\
-50.05\end{array}$ & $\begin{array}{l}326.50 / \\
-60.89\end{array}$ & $\begin{array}{l}312.06 / \\
-72.55\end{array}$ & $\begin{array}{l}282.55 / \\
-72.27\end{array}$ & $\begin{array}{l}261.30 / \\
-75.41\end{array}$ \\
\hline $24: 00$ & $\begin{array}{l}280.07 /- \\
86.12\end{array}$ & $\begin{array}{l}328.92 / \\
-79.74\end{array}$ & $\begin{array}{l}347.80 / \\
-69.81\end{array}$ & $\begin{array}{l}356.54 / \\
-58.29\end{array}$ & $\begin{array}{l}358.74 / \\
-49.26\end{array}$ & $\begin{array}{l}357.53 / \\
-44.81\end{array}$ & $\begin{array}{l}355.50 / \\
-46.55\end{array}$ & $\begin{array}{l}355.00 / \\
-54.07\end{array}$ & $\begin{array}{l}358.58 / \\
-65.21\end{array}$ & $\begin{array}{l}350.94 / \\
-77.73\end{array}$ & $\begin{array}{l}331.14 / \\
-86.29\end{array}$ & $\begin{array}{l}204.81 / \\
-88.40\end{array}$ \\
\hline
\end{tabular}

